\title{
PKM : Peningkatan SDM pada Pengerajin Lidi dan Batik di Desa Pondoknongko, Kecamatan Kabat, Banyuwangi
}

\author{
Genny Luhung Prasojo ${ }^{1}$, Ahmad Hariri ${ }^{2 凶}$, Rifki Arif ${ }^{3}$, Ikhwanul Qiram ${ }^{4}$ \\ gprasojo@gmail.com ${ }^{1}$, ahmadhariri@icpa-banyuwangi.ac.id ${ }^{2}$,rifkiaissix@gmail.com ${ }^{3}$,ikhwanulqiram@gmail.com ${ }^{4}$ \\ Correspondence Author ${ }^{2}$ \\ 1,2,3 Akademi Penerbang Indonesia, Banyuwangi \\ ${ }^{4}$ Program Studi Teknik Mesin, Fakultas Teknik, Universitas PGRI Banyuwangi
}

\begin{abstract}
Abstrak - UMKM kerajinan Lidi dan Batik di Desa Pondoknongko, Kecamatan Kabat, Kabupaten Banyuwangi adalah kelompok usaha produktif masyarakat yang menjadi ikon masyarakat Banyuwangi. Aktifitas usaha yang dilakukan selama ini masih konvensional sehingga berdampak terhadap kapasitas produksi yang belum optimal. Tujuan kegiatan pengabdian kepada masyarakat ini adalah dengan memberikan IPTEK berupa inovasi seni dan manajemen usaha yang lebih baik. Kegiatan dilakukan dengan kegiatan pelatihan yang didampingi oleh narasumber yang telah berpengalaman dan memiliki jaringan yang cukup luas. Hasil dari kegiatan pengabdian yang akan dilakukan menunjukkan bahwa usaha yang telah berjalan memiliki potensi sangat bagus dengan nilai ekonomis yang cukup tinggi dan meningkatkan penyerapan tenaga kerja. Beberapa produk inovasi juga dikembangkan meliputi aksesoris, hiasan dinding serta peralatan rumah tangga dan lain sebagainya. Kegiatan pendampingan ini telah membantu usaha masyarakat Pondoknongko agar dapat lebih maju dan berkembang.
\end{abstract}

\section{Kata Kunci - Pendampingan usaha, UMKM, Pengerajin Seni}

\begin{abstract}
The stick and batik craft UMKM in Pondoknongko Village, Kabat District, Banyuwangi Regency is a community productive business group that has become an icon of the Banyuwangi community. The business activities carried out so far are still conventional, resulting in suboptimal production capacity. The purpose of this community service activity is to provide science and technology in the form of artistic innovation and better business management. Activities carried out with training activities accompanied by resource persons who are experienced and have a fairly extensive network. The results of the community service activities that will be carried out show that the business that has been running has very good potential with a fairly high economic value and increases the absorption of labor. Several innovative products were also developed including accessories, wall hangings, and household appliances, and so on. This mentoring activity has helped the Pondoknongko community's efforts to progress and develop.
\end{abstract}

Keywords - Business assistance, UMKM, craftsmen

\section{Pendahuluan}

Pertumbuhan pariwisata di Kabupaten Banyuwangi mengalami peningkatan signifikan dalam 10 Tahun terakhir. Data wisatawan yang berkunjung pada 2013 mencapai 1.057 .952 orang, sementara wisatawan mancanegara mencapai 10.462 orang dan mengalami rata-rata peningkatan $30 \%$ setiap tahunnya [1]. Kondisi ini menggambarkan bahwa bisnis pariwisata dapat memberikan kesejahteraan melalui pemerataan kesempatan kerja dan lapangan pekerjaan melalui pendayaguaan objek dan daya tarik wisata [2].

Akademi Penerbang Indonesia (API) merupakan Perguruan Tinggi Negeri milik Kementrian Perhubungan yang berada di Kabupaten Banyuwangi. Keberadaan API Banyuwangi merupakan bagian dari upaya penunjang sektor pendidikan penerbang setelah berdirinya Bandara Blimbingsari. API Banyuwangi memiliki peran penting dalam pembangunan SDM yang bermutu khususnya dalam industri transportasi udara. Disisi lain moda transportasi sangat erat kaitanya dengan laju pertumbuhan ekonomi pariwisata [3].

Sebagai bagian dari fungsi tridharma perguruan tinggi, API Banyuwangi memiiki potensi Sumber Daya jaringan stakeholder yang cukup luas. Salah satu mitra dalam pengabdian masyarakat ini adalah UMKM yang berada di Desa Pondoknongko, Kecamatan Kabat, Banyuwangi. Desa Pondoknongko memiliki jumlah penduduk sebesar 3.187 jiwa [4]. $8,1 \%$ masyarakat Desa Pondoknongko berprofesi sebagai pedagang dan pengerajin seni berbahan dasar limbah alam seperti lidi, batik dan sebagainya. Produk yang telah dihasilkan dari limbah alam seperti lidi selama ini berupa peralatan makan, souvenir dan lain sebagainya. Sumber daya limbah alam ini seringkali masih belum diolah secara maksimal dan jika dikelola dengan baik dapat memiliki nilai seni dan ekonomi yang tinggi [5].

Ditengah permintaan pasokan produk kerajinan semakin meningkat akibat kunjungan wisata di 


\begin{abstract}
Kabupaten Banyuwangi, sejumlah masyarakat pengerajin Lidi dan Batik masih menemukan beberapa kendala untuk meningkatkan produksinya. Keterbatasan teknologi serta minimnya ruang informasi membuat sejumlah UMKM cukup kesulitan untuk mengembangan bisnisnya. Sejumlah pengerajin masih mengolah Lidi dan Batik dengan teknik konvensional atau menggunakan tenaga manusia. Hal ini berpengaruh terhadap kualitas dan efisiensi waktu produksi.

Disisi lain manajemen usaha yang dijalankan masih dilakukan dengan sangat sederhana. Belum tersedia tata kelola administratif pencatatan operasional yang baik. kondisi ini membuat biaya modal dan keuntungan yang diterima masih tercampur sehingga cukup sulit untuk melihat potensi keberlanjutan dan pengembangan usaha yang telah berjalan. Maka dari itu, berdasarkan dua aspek di atas, API Banyuwangi mencoba untuk memberikan upaya pendampingan usaha untuk meningkatkan peluang yang lebih baik bagi pengerajin lidi dan batik Desa Pondoknongko di masa depan.
\end{abstract}

\section{SOLUSI DAN LUARAN}

Dari potensi dan hambatan diatas, program yang dilakukan adalah melaksanakan pelatihan peningkatan SDM pelaku kerajinan dengan materi yang meliputi pelatihan penggunaan peralatan penunjang produksi, tata cara packaging, diversifikasi produk, dan manajemen usaha. Materi dititikberatkan pada pemanfaatan potensi lokal berupa hasil bumi yang dimiliki Desa Pondoknongko sebagai bahan baku produk yang akan diolah dan dijual.

\section{Metode Kegiatan}

Kegiatan pelatihan ini dilakukan di Balai Desa Pondoknongko, Kec. Kabat, Banyuwangi Muncar tanggal 09 Oktober 2020. Peserta pelatihan terdiri dari masyarakat pekerja kerajinan Lidi dan Batik sejumlah 20 orang, Kepala Desa, perwakilan tokoh Masyarakat, dan jajaran pimpinan API Banyuwangi.

Tahapan kegiatan meliputi :

1. Kordinasi teknis bersama aparat Desa terkait pra pelaksanaan

2. Pelaksanaan kegiatan pelatihan selama dua hari pada jam 08-15.00

3. Evaluasi pasca kegiatan

Dalam pelaksanaan kegiatan, API Banyuwangi turut serta menghadirkan Persatuan Dharma Wanita BPSDM Perhubungan. Dimana kehadiran Dharma wanita sebagai bagian upaya membangun silaturahmi dan pemberdayaan wanita di Desa Pondoknongko, Banyuwangi.

\section{Hasil Kegiatan}

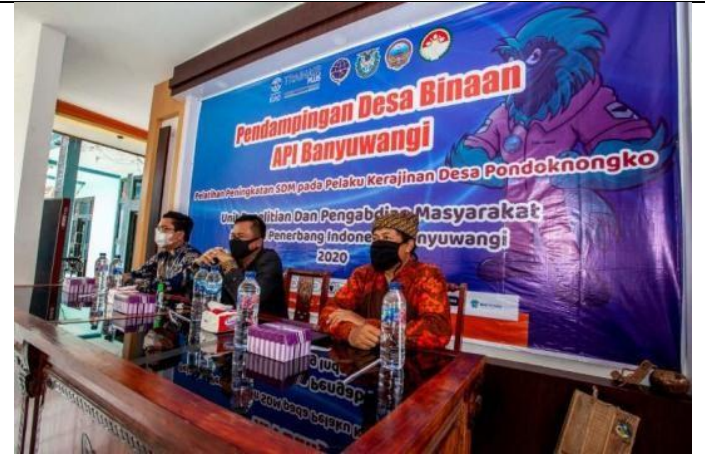

Gambar 1. Proses pembukaan acara
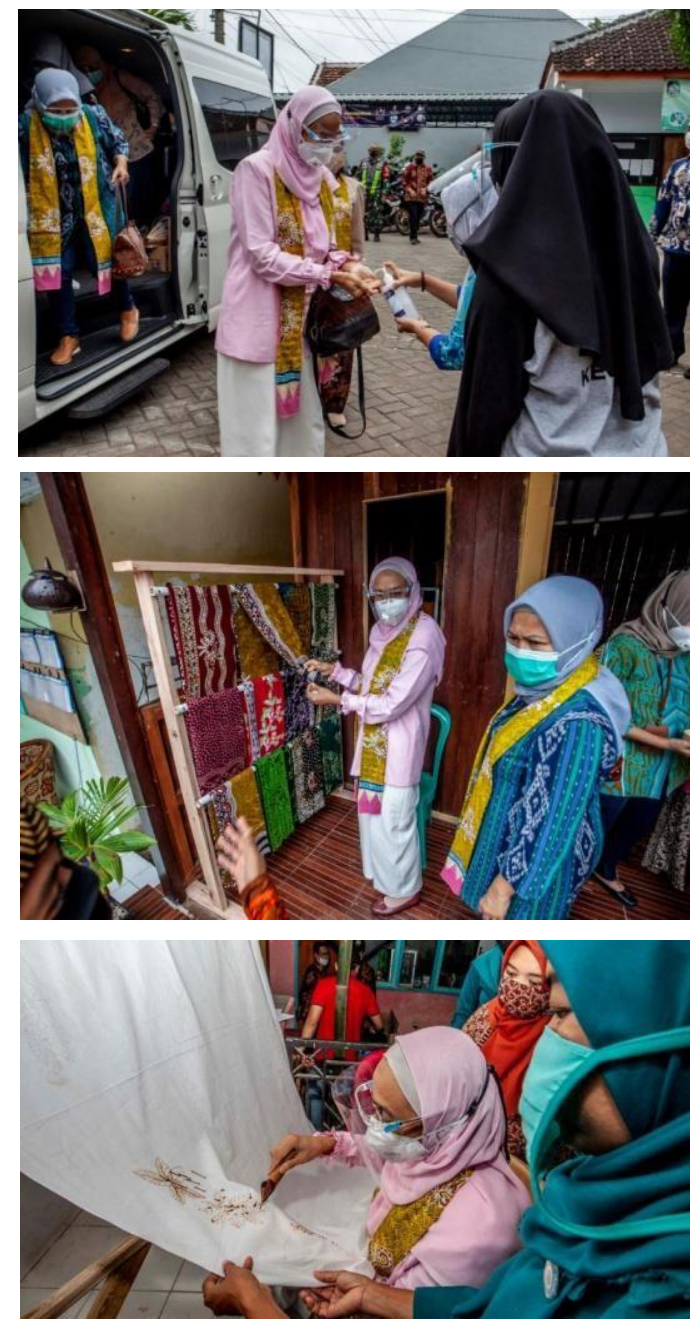

Gambar 2. Keterlibatan peran Dharma wanita BPSDM Perhubungan

Hasil dari pelaksanaan pelatihan usaha ini memberikan respon positif selama berlangsungnya kegiatan. Kegiatan juga berjalan dengan lancar dari perencanaan yang telah ditetapkan. Hasil evaluasi menunjukkan kondisi sebagai berikut : 


\begin{tabular}{|c|c|c|c|}
\hline \multicolumn{4}{|c|}{ Tabr 11. Evaluasi h sil kegiatan PKM } \\
\hline No & $\begin{array}{c}\text { Item } \\
\text { pengukuran }\end{array}$ & $\begin{array}{l}\text { Kondisi } \\
\text { sebelum }\end{array}$ & $\begin{array}{l}\text { Kondisi } \\
\text { sesudah }\end{array}$ \\
\hline $\mathbf{1}$ & $\begin{array}{l}\text { Pengetahuan } \\
\text { penggunaan } \\
\text { peralatan } \\
\text { penunjang }\end{array}$ & $\begin{array}{l}\text { Hanya } 20 \% \\
\text { pekerja } \\
\text { kerajinan } \\
\text { yang } \\
\text { memiliki } \\
\text { pengetahuan } \\
\text { dasar } \\
\text { penggunaan } \\
\text { alat }\end{array}$ & $\begin{array}{l}80 \% \text { peserta } \\
\text { mengetahui } \\
\text { tata cara } \\
\text { penggunaan } \\
\text { peralatan } \\
\text { teknis } \\
\text { penunjang } \\
\text { pembuatan } \\
\text { kerajinan }\end{array}$ \\
\hline 2 & $\begin{array}{l}\text { Tumbuhnya } \\
\text { kesadaran } \\
\text { penggunaan } \\
\text { alat modern } \\
\text { menunjang } \\
\text { peningkatan } \\
\text { produksi }\end{array}$ & $\begin{array}{l}\text { Hanya } 20 \% \\
\text { yang cukup } \\
\text { memahami } \\
\text { kebutuhan } \\
\text { tersebut }\end{array}$ & $\begin{array}{l}70 \% \text { peserta } \\
\text { menyadari, } \\
\text { dan } 30 \% \\
\text { masih } \\
\text { memiliki rasa } \\
\text { canggung } \\
\text { untuk } \\
\text { menggunakan } \\
\text { peralatan } \\
\text { listrik }\end{array}$ \\
\hline 3 & $\begin{array}{l}\text { Terjadi } \\
\text { peningkatan } \\
\text { kualitas } \\
\text { produk }\end{array}$ & $\begin{array}{l}\text { Hanya } 10 \% \\
\text { yang merasa } \\
\text { dengan } \\
\text { peralatan } \\
\text { penunjang } \\
\text { cukup } \\
\text { memberikan } \\
\text { perubahan } \\
\text { kualitas }\end{array}$ & $\begin{array}{l}100 \% \text { peserta } \\
\text { mengetahui } \\
\text { peningkatan } \\
\text { kualitas } \\
\text { produk }\end{array}$ \\
\hline 4 & $\begin{array}{l}\text { Pengetahuan } \\
\text { manajemen } \\
\text { usaha }\end{array}$ & $\begin{array}{l}20 \% \text { peserta } \\
\text { sudah cukup } \\
\text { baik }\end{array}$ & $\begin{array}{l}80 \% \text { peserta } \\
\text { mampu } \\
\text { menerapkan } \\
\text { tata kelola } \\
\text { administrasi } \\
\text { usaha yang } \\
\text { lebih baik }\end{array}$ \\
\hline
\end{tabular}

Dari tabel 1 telah ditunjukkan bahwa, hasil pelatihan memberikan dampak yang signifikan terhadap penguatan IPTEK bagi pengerajin lidi dan batik di Desa Pondoknongko Banyuwangi. Melihat respon yang cukup positif, maka hubungan kemitraan masyarakat API Banyuwangi dapat dikembangkan menjadi kegiatan yang memberikan konstribusi nyata dalam mendukung industri pariwisata di Banyuwangi.

\section{KESIMPULAN}

Kegiatan pengabdian ini adalah upaya peningkatan kesejahteraan masyarakat khususnya para ibu-ibu ruah tangga. Dengan memaksimalkan sumber daya manusia dan SDM yang unggul, maka berbagai peluang usaha dapat tercipta. Dari kegiatan pengabdian masyarakat ini juga memberikan dampak signifikan bagi civitas akademika API Banyuwangi dalam memberikan konstribusi nyata dalam pembangunan masyarakat Banyuwangi khususnya di

Desa Pondoknongko Kecamatan Kabat Banyuwangi.

\section{UCAPAN TERIMA KASIH}

Penulis mengucapkan terimakasih kepada Kepala Desa Pondok Pondoknongko dan segenap jajarannya. Ucapan terimakasih juga disampaikan kepada Persatuan Dharma Wanita BPSDM Perhubungan, UPPM dan segenap jajaran API Banyuwangi melalui dukungan yang diberikan dalam Program Kemitraan bagi Masyarakat tahun 2020.

\section{DAFTAR PUSTAKA}

[1]. Prospek industri pariwisata di Banyuwangi, https://bappeda.banyuwangikab.go.id/page/berita /prospek-industri-pariwisata-di-banyuwangi, Disadur tanggal 18 April 2020, 12:08 WIB

[2]. Lisa Umami (2013) Pengaruh Pariwisata Terhadap Perkembangan Kerajinan Batik Pajimatan Giriloyo Imogiri, Skripsi, Fakultas Bahasa dan Seni, Universitas Negeri Yogyakarta

[3]. Nyoman Budiartha R.M (2011) Studi Kasus : Pemilihan Daerah Tujuan Wisata (Dtw/Destinasi) oleh Wisatawan di Bali, Jurnal Ilmiah Teknik Sipil Vol. 15, No. 2

[4]. Demografi Desa Pondoknongko, http://pondoknongko.desa.id/web/detailnews/asp ek-demografi-desa-pondoknongko, Ditinjau tanggal 01 Februari 2021, 07:48 WIB

[5]. Desak Putu Parmiti, I Wayan Widiana, I Nyoman Aracana (2016) Pelatihan Kerajinan Tempurung Kelapa Di Desa Tianyar, Jurnal Widya Laksana, Vol. 5, No.1, P-ISSN: 1410-4369 